ARTICLE

Received 16 Jan 2013 | Accepted 16 Aug 2013 | Published 16 Sep $2013 \quad$ DOl: 10.1038/ncomms3455 OPEN

\title{
Osmium isotope evidence for a large Late Triassic impact event
}

Honami Sato ${ }^{1, \dagger}$, Tetsuji Onoue ${ }^{1, \dagger}$, Tatsuo Nozaki $^{2} \&$ Katsuhiko Suzuki ${ }^{2}$

Anomalously high platinum group element concentrations have previously been reported for Upper Triassic deep-sea sediments, which are interpreted to be derived from an extraterrestrial impact event. Here we report the osmium (Os) isotope fingerprint of an extraterrestrial impact from Upper Triassic chert successions in Japan. Os isotope data exhibit a marked negative excursion from an initial Os isotope ratio $\left({ }^{187} \mathrm{Os} /{ }^{188} \mathrm{Os}_{i}\right)$ of $\sim 0.477$ to unradiogenic values of $\sim 0.126$ in a platinum group element-enriched claystone layer, indicating the input of meteorite-derived Os into the sediments. The timing of the Os isotope excursion coincides with both elevated Os concentrations and low $\mathrm{Re} / \mathrm{Os}$ ratios. The magnitude of this negative Os isotope excursion is comparable to those found at CretaceousPaleogene boundary sites. These geochemical lines of evidence demonstrate that a large impactor (3.3-7.8 km in diameter) produced a global decrease in seawater ${ }^{187} \mathrm{Os} /{ }^{188} \mathrm{Os}$ ratios in the Late Triassic.

\footnotetext{
${ }^{1}$ Department of Earth and Environmental Sciences, Kagoshima University, 1-21-35 Korimoto, Kagoshima 890-0065, Japan. ${ }^{2}$ Institute for Research on Earth Evolution (IFREE), Japan Agency for Marine-Earth Science and Technology (JAMSTEC), 2-15 Natsushima-cho, Yokosuka, Kanagawa 237-0061, Japan. $\dagger$ Present addresses: Department of Earth and Planetary Sciences, Kyushu University, 6-10-1 Hakozaki, Higashi-ku, Fukuoka 812-8581, Japan (H.S.); Department of Earth and Environmental Sciences, Kumamoto University, 2-39-1 Kurokami, Kumamoto 860-8555, Japan (T.O.). Correspondence and requests for materials should be addressed to H.S. (email: 3SC12024G@s.kyushu-u.ac.jp).
} 
T he Late Triassic was characterized by several marine and terrestrial biotic turnover events before the end-Triassic mass extinction ${ }^{1,2}$. The causes of the end-Triassic mass extinction and Norian-to-Rhaetian biotic turnover events are still the subject of active debate. Catastrophic processes, such as widespread eruption of the Central Atlantic Magmatic Province flood basalts, and extraterrestrial impacts have been proposed to account for the biotic turnover events ${ }^{1}$. Impact ejecta layers have been found in the Norian terrestrial sections ${ }^{3-5}$. A Norian deposit in southwestern Britain contains microspherules and shocked quartz that are typical of impact ejecta layers, and it has been suggested that the Manicouagan impact structure in Canada $(100 \mathrm{~km}$ diameter; $\sim 215 \mathrm{Ma})$ may be the source of the spherules ${ }^{4,5}$. A Norian impact event has been inferred from a platinum group element (PGE) concentration anomaly, and the presence of Ni-rich magnetite and microspherules, in a claystone layer within middle Norian bedded chert succession in the Sakahogi section, Mino Terrane, central Japan ${ }^{3}$. These claystone samples have high PGE concentrations of up to $11.4 \mathrm{ng} \mathrm{g}^{-1}$ osmium (Os), $41.5 \mathrm{ngg}^{-1}$ Ir, $46.0 \mathrm{ngg}^{-1} \mathrm{Ru}$ and $20.3 \mathrm{ng} \mathrm{g}^{-1} \mathrm{Pt}$, which are comparable to those found at the Cretaceous-Paleogene (K-Pg) boundary ${ }^{6,7}$. Given that PGEs are highly depleted in Earth's continental crust relative to solar abundances ${ }^{8,9}$, these anomalously high PGE abundances may have resulted from a large extraterrestrial impactor, similar to the Chicxulub impact event at the K-Pg boundary ${ }^{6,7}$. However, previous studies have proposed that redistribution of PGEs under reducing conditions can account for PGE enrichments in deepsea sediments ${ }^{10,11}$, and it remains unclear as to whether the anomalous PGE concentrations in these middle Norian sediments are of meteoritic origin.

Here, to identify the origin of the anomalously high PGE abundances in these Norian sediments from Japan, we conduct an Os isotope study of the sediments ${ }^{12-15}$. Seawater ${ }^{187} \mathrm{Os} /{ }^{188} \mathrm{Os}$ ratios reflect contributions to the global ocean from riverine $\left({ }^{187} \mathrm{Os} /{ }^{188} \mathrm{Os} \approx 1.4\right)$, and hydrothermal and extraterrestrial inputs $\left({ }^{187} \mathrm{Os} /{ }^{188} \mathrm{Os} \approx 0.12-0.13\right)^{15}$. Given the distinctive ${ }^{187} \mathrm{Os} /{ }^{188} \mathrm{Os}$ ratios of these inputs and the relatively short residence time of Os in the ocean (several tens of thousand years ${ }^{16}$ ), seawater ${ }^{187} \mathrm{Os} /$ ${ }^{188} \mathrm{Os}$ ratios are highly sensitive to changes in these fluxes. For example, Os isotope data have been used to infer that an abrupt decline in seawater ${ }^{187} \mathrm{Os} /{ }^{188} \mathrm{Os}$ ratios occurred during the late Eocene $^{14}$, and at the K-Pg boundary, marking the 65-Ma impact event at Chicxulub in Mexico ${ }^{13,17} \cdot{ }^{187} \mathrm{Os} /{ }^{88} \mathrm{Os}$ ratios of the Norian bedded chert successions in the Sakahogi section are determined to search for evidence of an extraterrestrial input. To validate our interpretation of the Os isotope record from the Sakahogi section, a complementary Os isotope study is conducted on middle Norian bedded cherts of the Enoura section, located $c a$. $600 \mathrm{~km}$ from the Sakahogi section (Supplementary Figs S1-S4). These bedded cherts are considered to be deep-sea sediments that accumulated in a pelagic, open ocean setting within the paleo-Pacific Ocean (Panthalassa) ${ }^{18-20}$. We reconstruct a highresolution paleo-seawater Os isotope profile for the middle Norian. The major element geochemical compositions of the bedded chert succession in the Sakahogi section are also obtained to place further constraints on the source of Os in the PGE-enriched layer.

\section{Results}

Geologic setting and sample collection. Chert and claystone samples for Os isotope analysis were collected from the Sakahogi section, Mino Terrane, central Japan, where the PGE geochemistry has previously been investigated ${ }^{3}$ (Supplementary Fig. S2). A previous paleomagnetic study of the Sakahogi section suggests that these sediments accumulated in a pelagic, open ocean setting within the low-latitudinal zone of the Panthalassa Ocean ${ }^{18,21}$ (Fig. 1). The claystone layer with high PGE abundances is $4.4 \mathrm{~cm}$ thick. We distinguish lower and upper sedimentary sublayers within the claystone (Fig. 2). The lower sublayer ( $\sim 8 \mathrm{~mm}$ thick) is characterized by high PGE concentrations, and comprises clinochlore-rich chlorite microspherules and Ni-rich magnetitespinel in a matrix of clay minerals (mainly illite), cryptocrystalline quartz and haematite (Supplementary Fig. S5). The upper sublayer is undisturbed sediments whose constituent minerals are clays (illite) and cryptocrystalline quartz, along with radiolarians, siliceous sponge spicules and conodonts. Biostratigraphic analysis of radiolarians and conodonts dates the deposit to upper middle Norian age (Fig. 1). Given that the constant average sedimentation rate of the middle Norian chert succession is $1.0 \mathrm{~mm} \mathrm{kyr}^{-1}$ (ref. 3), the deposition of the claystone layer occurred $\sim 1 \mathrm{Myr}$ before the middle/upper Norian boundary $(\sim 214 \mathrm{Ma})^{22}$ and the duration of deposition at the studied section $(65 \mathrm{~cm}$ thick) is estimated to be $0.65 \mathrm{Myr}$. Previous studies have found no geological or geochemical evidence of hydrothermal activity in the studied bedded chert successions ${ }^{18,19,23}$. Moreover, the redistribution of PGEs in the studied stratigraphic interval is minor, as there is no evidence of downward diagenetic PGE remobilization from the lower sublayer claystone (Supplementary Fig. S6).

Samples for whole-rock geochemical analysis were collected from 19 chert beds across the claystone layer (Fig. 2). Veins and strongly recrystallized/weathered parts of the chert beds were avoided to minimize the effects of diagenetic or metamorphic overprinting on the sediment geochemistry. We also collected six

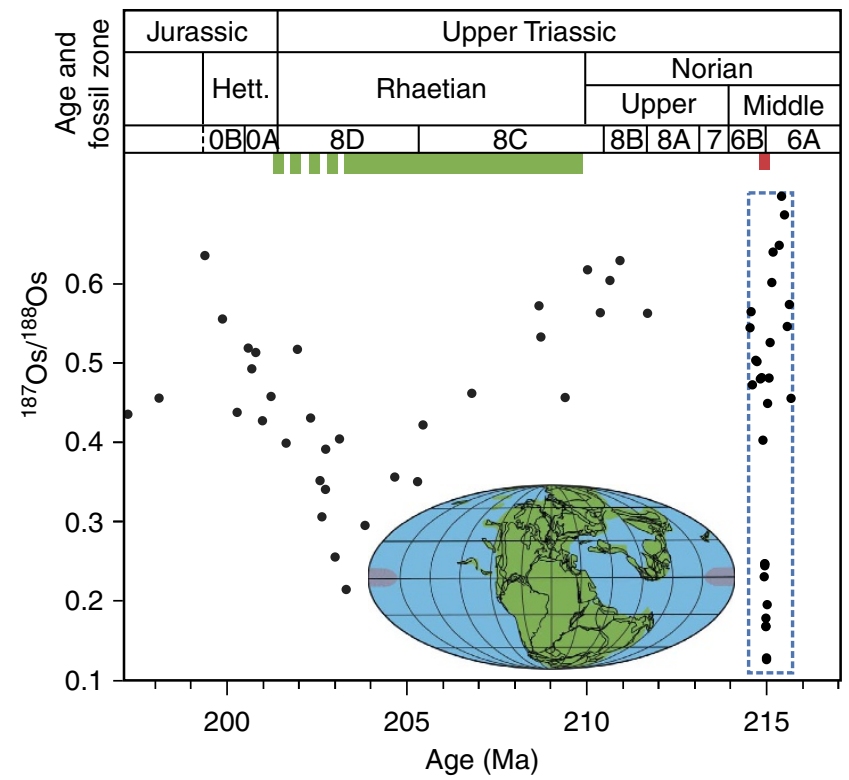

Figure 1 | Late Triassic Os isotope record in the Panthalassa Ocean. A gradual decrease in ${ }^{187} \mathrm{Os} /{ }^{188}$ Os ratios during the Rhaetian (see insert for continental configuration) is considered to have been closely linked with the Central Atlantic Magmatic Province (CAMP) volcanic event (green shaded area $)^{44}$, whereas the abrupt decrease of ${ }^{187} \mathrm{Os} /{ }^{188} \mathrm{Os}$ ratios in the middle Norian is synchronous with the $\sim 215$ Ma Manicouagan impact event (red bar) ${ }^{3}$. The blue dashed box outlines the Os isotope data obtained in this study (Fig. 4). The grey circles represent Os isotope data reported by Kuroda et al. ${ }^{44}$ The geologic time scale was taken from Ogg 22 . The red shaded area on the paleogeographic map shows the estimated depositional site of the bedded chert within the Mino Terrane ${ }^{18}$. Fossil (radiolarian) zones 6A through $\mathrm{OB}$ are from Onoue et al. ${ }^{3}$ 

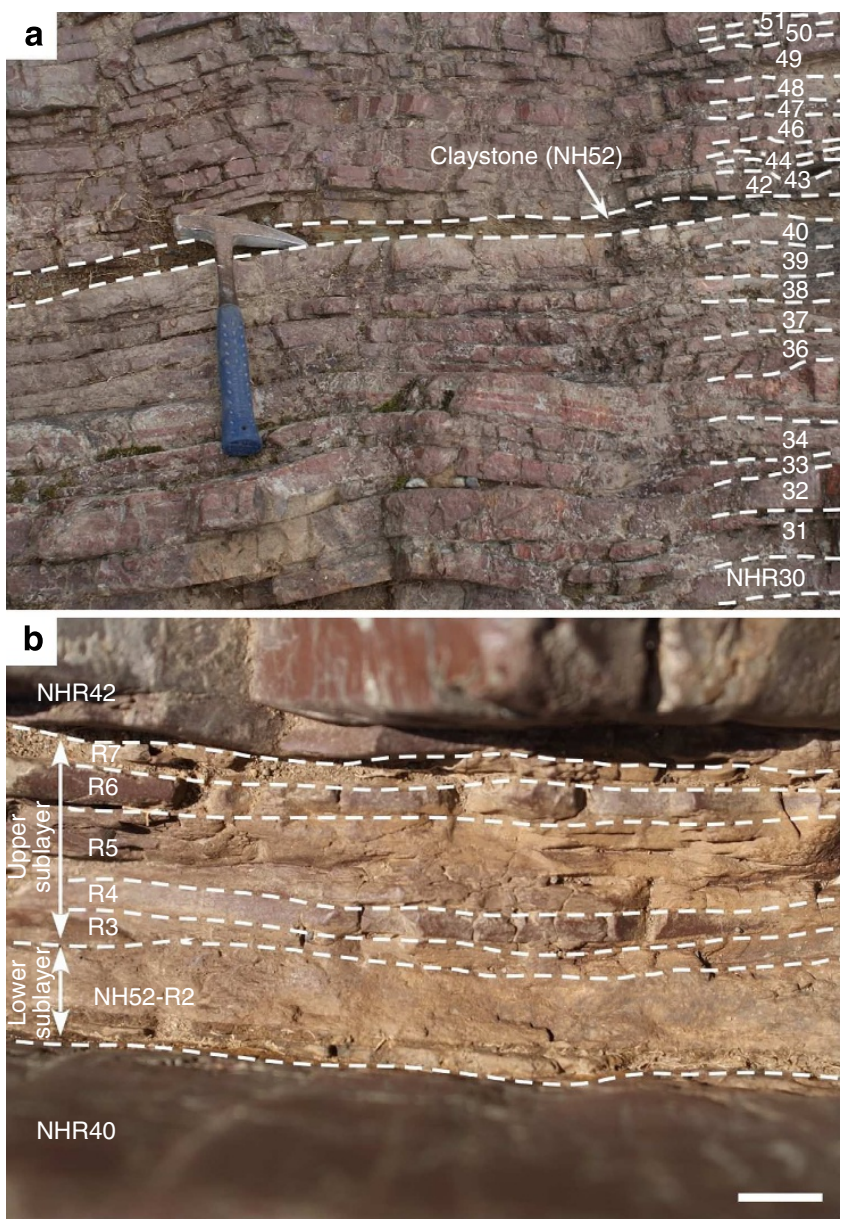

Figure 2 | Upper Triassic bedded chert of the Sakahogi section.

(a) Outcrop view of the claystone bed in the middle Norian bedded chert succession at the Sakahogi section. Numbers NHR30 to 51 refer to individual beds. See bed numbers NHR30 to NHR51 of Fig. 4.

(b) Photograph showing detailed occurrence of claystone bed (NH52) at the Sakahogi section. The claystone bed is subdivided into six samples, NH52-R2 to R7 (see text for detail). Note that beds NH52-R4 and R6 contain radiolarians, siliceous sponge spicules and conodonts in a matrix of clay minerals and cryptocrystalline quartz. See bed numbers NH52-R2 to NH52-R7 of Fig. 4. Scale bar, $1 \mathrm{~cm}$.

claystone samples from the lower and upper sublayers. The relatively thick upper sublayer $(\sim 3.6 \mathrm{~cm})$ was subdivided into five samples on the basis of colour, lithology, $\mathrm{SiO}_{2}$ content and biogenic content (Fig. 2). $\mathrm{SiO}_{2}$-rich parts of samples NH52-R4 and NH52-R6 contain abundant radiolarians and sponge spicules, and are laterally continuous in the claystone layer (Fig. 3 and Supplementary Fig. S7).

To examine whether the Os isotope trends of the Sakahogi section are a global feature, we also studied another middle Norian bedded chert succession from the Enoura section, Chichibu Terrane, southwest Japan (Supplementary Fig. S8). Paleomagnetic analysis of these Triassic bedded cherts, located $600 \mathrm{~km}$ from the Sakahogi section, suggests that the depositional setting of these cherts was along the paleo-equator in the Middle Triassic ${ }^{20}$. The Sakahogi cherts accumulated at higher latitudes $\left(16.9^{\circ} \pm 10.2^{\circ} \mathrm{N}\right.$ or $\left.\mathrm{S}\right)$ than the Enoura cherts $\left(2.1^{\circ} \pm 5.2^{\circ} \mathrm{N}\right.$ or $\left.\mathrm{S}\right)$ during the Middle Triassic, as deduced from paleomagnetic data $^{20,21}$, and this indicates that the depositional sites of the two cherts were separated by more than a $1,000 \mathrm{~km}$. At this time, an oceanic plate on which the Enoura Triassic cherts were deposited moved towards the continental margin of East Asia and was accreted during the Middle Jurassic at a lower latitude than the Sakahogi cherts ${ }^{20}$. We analysed nine chert and four claystone samples from the Enoura section (Supplementary Table S1).

Re and Os geochemistry. Average Re and Os concentrations in the chert samples from the Sakahogi section are 10.5 and $5.4 \mathrm{pg} \mathrm{g}^{-1}$, respectively, which are much lower than those of the claystone samples (Supplementary Table S2). Os concentrations in the lower sublayer of the claystone (NH52-R2) are as high as 3.0-3.1 $\mathrm{ng} \mathrm{g}^{-1}$ and gradually decrease upwards through the upper sublayer (NH52-R3 to NH52-R7) from 0.20 to $0.07 \mathrm{ng} \mathrm{g}^{-1}$. The lower sublayer is distinctly enriched in Os relative to surrounding sediments, and our results are consistent with those reported by Onoue et $\mathrm{al}^{3}$ The lower sublayer of the claystone is characterized by the highest $\mathrm{Re}$ concentration $\left(\sim 0.11 \mathrm{ngg}^{-1}\right)$ and lowest $\mathrm{Re} / \mathrm{Os}$ ratio $(\sim 0.03)$ of the analysed samples (Fig. 4). Re/Os ratios of the chert samples range from 1.00 to 4.19 , and are higher than those of the claystone samples. Changes in Re and Os concentrations of the Enoura chert and claystone samples are similar to those of the Sakahogi section, despite the lower sample resolution in the Enoura section (Supplementary Fig. S8). The spherule-rich lower part of the claystone in the Enoura section is also characterized by the highest Os concentrations $\left(\sim 1.2 \mathrm{ngg}^{-1}\right)$ and lowest Re/Os ratios $(\sim 0.10)$ of the studied section (Supplementary Table S1).

Initial Os isotope ratios of the chert samples $\left({ }^{187} \mathrm{Os} /\right.$ $\left.{ }^{188} \mathrm{Os}_{i}=0.400-0.704\right)$ from the Sakahogi section are relatively homogeneous and higher than those of the claystones. ${ }^{187} \mathrm{Os} /$ ${ }^{188} \mathrm{Os}_{i}$ ratios decline abruptly from 0.477 to 0.126 in the lower sublayer of the claystone (Fig. 4). This marked negative shift in ${ }^{187} \mathrm{Os} /{ }^{188} \mathrm{Os}_{i}$ ratios was confirmed by duplicate analyses (Supplementary Table S2). In the upper sublayer, ${ }^{187} \mathrm{Os} /{ }^{188} \mathrm{Os}_{i}$ ratios gradually increase from 0.178 to 0.234 (NH52-R3 to NH52R7-1, respectively). Chert samples overlying the claystone layer (NHR42 to NHR51) have ${ }^{187} \mathrm{Os} /{ }^{188} \mathrm{Os}_{i}$ ratios that gradually increase from 0.446 to 0.540 , which, on average, are similar to those of chert samples below the claystone (NHR30 to NHR40). The same Os isotope shift is also observed from the Enoura section across the claystone layer (Supplementary Fig. S8).

Major element geochemistry. The major element compositions of the chert and claystone samples of the Sakahogi section are analogous to the previously published data of the sediments from the Inuyama Area ${ }^{23}$, several hundred metres away from the Sakahogi section, except for the lower sublayer of the claystone (Supplementary Table S3). The negative correlations among $\mathrm{SiO}_{2}$ versus $\mathrm{Al}_{2} \mathrm{O}_{3}, \mathrm{MgO}$ and $\mathrm{Fe}_{2} \mathrm{O}_{3}$ (total iron as $\mathrm{Fe}_{2} \mathrm{O}_{3}$ ) concentrations indicate that our samples have been formed by mixing of biogenic silica (radiolarian test) and terrestrial components (aeolian dusts) derived from the continental crust ${ }^{23}$ (Fig. 5). A high $\mathrm{Al} /(\mathrm{Al}+\mathrm{Fe}+\mathrm{Mn})$ ratio indicates that the Sakahogi bedded cherts were deposited in a pelagic deep-sea environment without the affection by hydrothermal activity (Supplementary Fig. S9). The lower sublayer claystone (NH52-R2) exhibits higher $\mathrm{MgO}$, $\mathrm{TiO}_{2}, \mathrm{MnO}$ and $\mathrm{Fe}_{2} \mathrm{O}_{3}$ (total iron as $\mathrm{Fe}_{2} \mathrm{O}_{3}$ ) concentrations than those of other upper claystone samples.

\section{Discussion}

Our data from the Sakahogi section reveal the presence of anomalously high Os abundances up to $3.1 \times 10^{3} \mathrm{pg} \mathrm{g}^{-1}$ within the lower sublayer of the claystone (NH52-R2), which is three orders of magnitude higher than those of the chert samples $\left(\sim 5.4 \mathrm{pg} \mathrm{g}^{-1}\right)$. Variations in the Os and other PGE concentrations of the chert and claystone samples are mainly attributable to the 

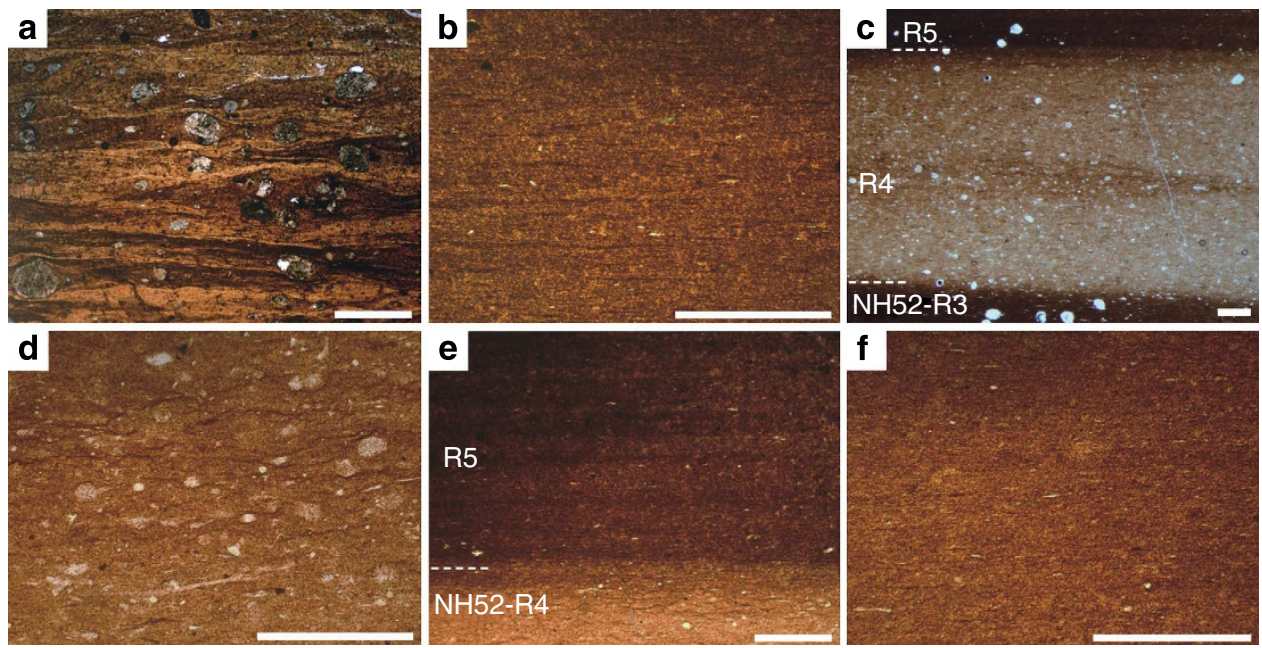

Figure 3 | Photomicrographs of the claystones from the Sakahogi section. (a) Microspherules from the lower sublayer claystone (NH52-R2).

(b) Homogeneous upper claystone (NH52-R3) having no microspherules just above the lower subylayer. (c) Thin intercalation of radiolarian-rich clay (NH52-R4) in the upper sublayer claystone. (d) Abundant radiolarians contained in NH52-R4. (e,f) Crudely laminated clay (NH52-R5) showing no sediment disturbance in the upper sublayer. Scale bars, $500 \mu \mathrm{m}$. Plane-polarized light.

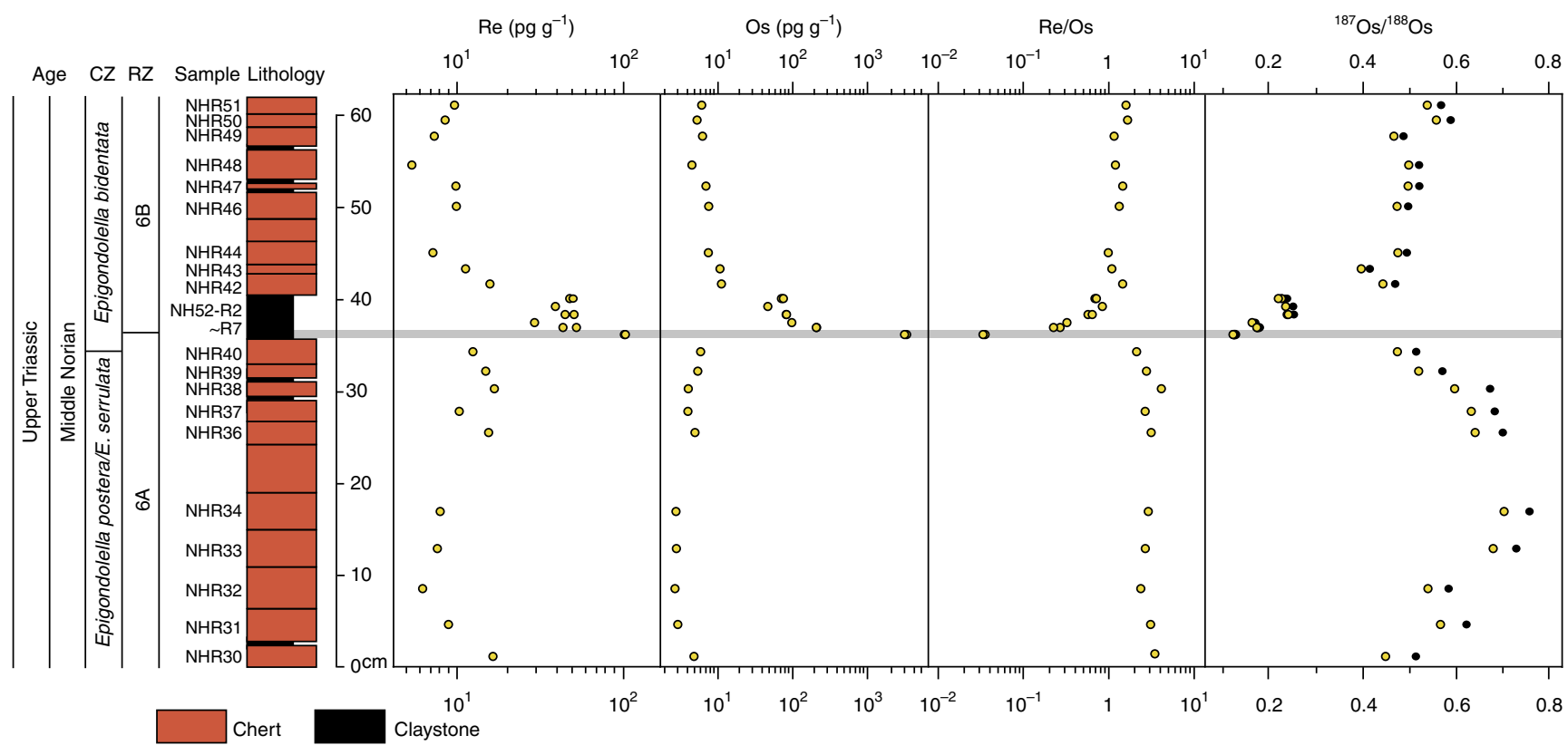

Figure 4 | Stratigraphic Os isotope profile. Stratigraphic profiles of Re and Os concentrations, Re/Os ratios and Os isotope ratios in bedded cherts of the Sakahogi section. Yellow and black dots in the Os isotope profile represent age-corrected $\left({ }^{187} \mathrm{Os} /{ }^{188} \mathrm{Os}_{i} ; i=215 \mathrm{Ma}\right)$ and measured isotope ratios, respectively. The grey shaded line highlights the stratigraphic position of the lower sublayer claystone. Conodont (CZ) and radiolarian (RZ) zones are from Onoue et al. ${ }^{3}$

different contributions from terrigenous components, apart from the lower sublayer claystone. On the basis of mineralogy and major element chemistry, the claystone samples contain a greater terrigenous component than the chert samples ${ }^{23}$ (Fig. 5), suggesting that the higher Os concentrations of the claystone as compared with the chert samples reflects the dominance of terrigenous Os in claystone relative to chert. However, the lower sublayer claystone has extremely high Os concentrations as compared with typical upper continental crust $\left(31 \mathrm{pgg}^{-1}\right)^{8}$, oceanic crust $\left(21-33 \mathrm{pg} \mathrm{g}^{-1}\right)^{24}$ and other claystone samples from our studied section (NH52-R3, NH52-R5 and NH52-R7). Therefore, the high Os concentrations of the lower sublayer cannot originate from terrigenous input. One possible Os enrichment mechanism is the formation of authigenic ferromanganese minerals in a pelagic deep-water setting ${ }^{25,26}$. This mechanism for Os enrichment is, however, inconsistent with the absence of a positive correlation between $\mathrm{MnO}$ and Os contents (Supplementary Tables S2 and S3).

The lower sublayer samples from the Sakahogi section have unique geochemical signatures, such as anomalously high Os contents $\left(\sim 3.1 \times 10^{3} \mathrm{pgg}^{-1}\right)$, low $\mathrm{Re} / \mathrm{Os}$ ratios $(\sim 0.03)$ and unradiogenic ${ }^{187} \mathrm{Os} /{ }^{188} \mathrm{Os}_{i}$ ratios $(\sim 0.126)$, all of which suggest a significant extraterrestrial Os input to the sediments ${ }^{12,14,17}$. Most meteorites that reach the Earth's surface (for example, chondrites and irons) have relatively low $\mathrm{Re}$ and high Os abundances, and Re/Os $\leq 0.1$ (refs 12,27). In contrast, the 


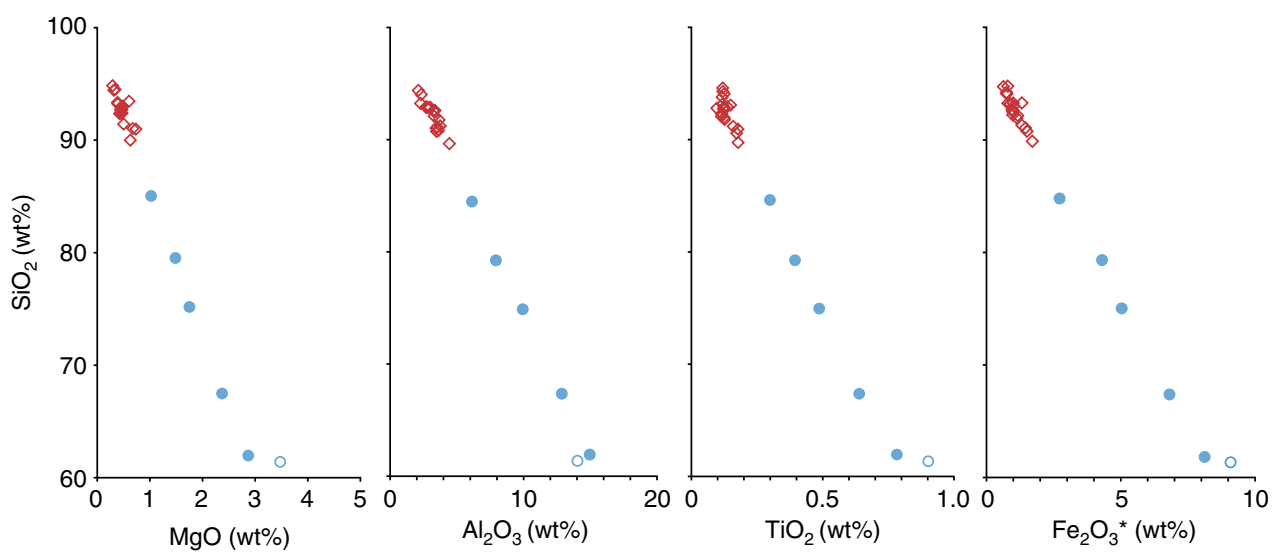

Figure 5 | Major element compositions of chert and claystone. $\mathrm{SiO}_{2}$ versus $\mathrm{MgO}, \mathrm{Al}_{2} \mathrm{O}_{3}, \mathrm{TiO}_{2}$ and $\mathrm{Fe}_{2} \mathrm{O}_{3}$ (total iron as $\mathrm{Fe}_{2} \mathrm{O}_{3}$ ) diagrams of the $\mathrm{Sakahogi}$ chert (red open diamonds), and lower (blue open circles) and upper (blue closed circles) claystone samples show negative correlation, indicating mixing of biogenic silica (radiolarian test) and terrestrial components (aeolian dusts) derived from the continental crust $^{23}$.

continental crust generally has Re/Os $>1$ (refs 8,12 ), as $\operatorname{Re}$ is a moderately incompatible element during partial melting of Earth's mantle. Element abundance ratios of $\mathrm{Pt}$ and $\mathrm{Ir}$ also support a distinctive PGEs source at the lower sublayer claystone (Supplementary Fig. S6) and indicate a remarkable contribution of meteoritic PGE by an impact event ${ }^{28}$. Moreover, the ${ }^{187} \mathrm{Os} /$ ${ }^{188} \mathrm{Os}_{i}$ ratio of the lower sublayer is similar to that of various chondrite types (Supplementary Table S4). A caveat is that ultramafic rocks with unradiogenic ${ }^{187} \mathrm{Os} /{ }^{188} \mathrm{Os}$ ratio $(0.12-$ $0.13)^{29}$ are a highly unlikely source of negative excursion of the lower sublayer claystone, because Os abundances in typical ultramafic rocks $\left(2.6 \mathrm{ngg}^{-1}\right)^{29}$ are less than that of the lower sublayer $\left(\sim 3.1 \mathrm{ng} \mathrm{g}^{-1}\right)$. Even if the ultramafic rock contains up to $5.2 \mathrm{ng} \mathrm{g}^{-1}$ Os with a ${ }^{187} \mathrm{Os} /{ }^{188} \mathrm{Os}$ ratio of 0.128 (ref. 29), a mixing calculation with terrigenous component $\left(31 \mathrm{pgg}^{-1}\right.$ Os and $\left.{ }^{187} \mathrm{Os} /{ }^{188} \mathrm{Os}=1.4\right)^{8}$ indicates that a $\sim 57 \%$ contribution by ultramafic rock is required to explain the high Os concentration of the lower sublayer claystone. On the basis of the detailed field investigation and microscopic observation, we could find no evidence supporting the ultramafic rock contribution, as with the major geochemical compositions of the lower sublayer claystone.

The low ${ }^{187} \mathrm{Os} /{ }^{188} \mathrm{Os}_{i}$ ratios in the claystone layer may have been produced by the mixing of ambient seawater Os with meteoritic Os that was vaporized at the time of impact and subsequently dissolved into seawater ${ }^{14}$. A previous petrological study revealed that only the lower sublayer claystone contains abundant spherules and Ni-rich magnetite grains (Fig. 3). Therefore, Os included in the impact-derived particles was added directly into the lower sublayer claystone, not via vaporization and dissolution into seawater. As such, Os isotope data from the lower sublayer claystone were excluded from our reconstruction of the secular variation of 'seawater' ${ }^{187} \mathrm{Os} /{ }^{188} \mathrm{Os}$ ratios during the middle Norian impact event. Although our thin-section observations reveal no evidence of bioturbation and reworking (for example, cross stratification, basal or internal scours, reversals or interruptions in grading) in the upper sublayer claystone (Fig. 3), we cannot completely rule out the possibility of contamination from the lower sublayer, induced by the resuspension of bottom currents, especially near the boundary between the lower and upper sublayer claystones (that is, between NH52-R2 and R3). To minimize the possibility of contamination by discrete extraterrestrial particles from the lower sublayer, we excluded the Os isotope values obtained for NH52-R3 when reconstructing the seawater ${ }^{187} \mathrm{Os} /{ }^{188} \mathrm{Os}$ ratio. Except for the lower sublayer and the basal upper sublayer claystones (NH52-R2 and R3), seawater
${ }^{187} \mathrm{Os} /{ }^{188} \mathrm{Os}_{i}$ ratios exhibit a short and marked negative excursion from 0.582 (average ${ }^{187} \mathrm{Os} /{ }^{188} \mathrm{Os}_{i}$ ratios of ten chert samples below the lower sublayer claystone) to 0.222 (average ${ }^{18} \mathrm{Os} /$ ${ }^{188} \mathrm{Os}_{i}$ ratios of four claystone samples of NH52-R4 to R7), which rapidly recovered to 0.446 . This abrupt and large change in ${ }^{187} \mathrm{Os} /{ }^{188} \mathrm{Os}_{i}$ ratios provides conclusive evidence for a middle Norian impact event similar to those that occurred in the late Eocen $^{14}$ and at the K-Pg boundary ${ }^{17}$. Moreover, the magnitude of this negative ${ }^{187} \mathrm{Os} /{ }^{188} \mathrm{Os}_{i}$ excursion is comparable to those of the late Eocene ( 0.5 to 0.28$)^{14}$ and at the K-Pg boundary ( 0.4 to $0.157)^{17}$, and implies that the middle Norian impactor was a large, kilometre-sized object with unradiogenic Os $\left({ }^{187} \mathrm{Os} /\right.$ ${ }^{188} \mathrm{Os}_{i} \approx 0.12$ )

The size of the impactor can be inferred from the sedimentary Os concentrations and isotope ratios, by making reasonable estimates of the range in the amount of Os released from the impactor into seawater ${ }^{14}$. Estimating the impactor size using such an approach is highly dependent on the assumed nature of the impactor. We consider that the PGEs in the lower sublayer claystone might have originated from a chondrite or iron meteorite, or from one of a small group of PGE-rich achondrites (for example, acapulcoites or ureilites ${ }^{30,31}$ ). A Howardite-eucritediogenite and/or Martian meteorite (shergottite, nakhlite and chassignite) impactor cannot account for the high PGE concentrations in the lower sublayer claystone, as these differentiated achondrites have much lower PGE concentrations (for example, 0.004-3.9 $\left.\mathrm{ng} \mathrm{g}^{-1} \mathrm{Ir}, 0.16-1.4 \mathrm{ng} \mathrm{g}^{-1} \mathrm{Pt}\right)^{32,33}$ than the lower sublayer claystone (30.0-32.5 $\mathrm{ngg}^{-1}$ Ir, 20.3-23.5 $\left.\mathrm{ngg}^{-1} \mathrm{Pt}\right)^{3}$. Assuming 22 to $100 \%$ release of chondrite-derived Os into seawater $6,14,34$, the impactor is calculated to be $3.3-7.8 \mathrm{~km}$ in diameter (Supplementary Table S4). If the impacting object was an iron meteorite that has a higher Os concentration than a chondrite (that is, $\left.35 \times 10^{3} \mathrm{ng} \mathrm{g}^{-1} \mathrm{Os},{ }^{187} \mathrm{Os} /{ }^{188} \mathrm{Os}=0.125, \rho=8 \mathrm{~g} \mathrm{~cm}^{-3}\right)^{35-37}$, and it also released the same amount of Os into seawater (22 to $100 \%)$, then the impactor is calculated to be $0.7-1.2 \mathrm{~km}$ in diameter. Irrespective of the choice of impactor type, from these calculations it is clear that a kilometre-sized impactor is required to explain the negative Os isotope excursion.

The size of the middle Norian impactor, as estimated from the marine Os isotope record obtained in our study, indicates that a large amount of debris and/or climatically active gases (for example, sulphur and carbon dioxide) released from the impact site $6,38,39$ must have affected the physical, chemical and biological environments in the pelagic realm. However, a radiolarian analysis of the Sakahogi ${ }^{3}$ and Enoura sections (Supplementary 
Table S5) provides no evidence for a mass extinction event across the claystone layer. In contrast, significant faunal turnover occurred $\sim 1$ Myr after the impact event and 18 radiolarian species became extinct at this level in the bedded chert ${ }^{3}$. It is possible that the impact triggered the extinction of these 18 radiolarian species, although the direct cause of their extinction remains unclear.

A recent review of the application of Os isotopes to paleoceanographic studies ${ }^{40}$ highlights that our work provides previously undiscovered evidence of a meteoritic Os isotope signature in Triassic deep-sea sediments, which now crop out in an accretionary complex (Fig. 1). It is likely that this impact ejecta layer must also be present in other bedded cherts within other accretionary complexes around the Circum-Pacific. Bedded chert successions, which deposited in the pelagic Pacific Ocean occur in accretionary complexes throughout eastern Russia, Japan, Philippines, New Zealand and western North America. These successions have a wide range of sedimentary ages with a duration of $250 \mathrm{Myr}$ from the Lower Carboniferous to Lower Cretaceous periods. Given that an impact event produced by a chondritic meteorite of $2 \mathrm{~km}$ in diameter is detectable using marine Os isotope records ${ }^{14}$, systematic Os isotope studies of these global bedded chert successions should enable the identification of impact events throughout this time. For example, analysis of Os isotope ratios in bedded cherts across the Permian-Triassic boundary 41 would enable testing of the hypothesis that an extraterrestrial impact produced this major biotic extinction event, as has been inferred from the possible discovery of shocked quartz grains and high abundances of Ir in sediments of this age ${ }^{42}$.

\section{Methods}

Re-Os isotope analysis. Re and Os concentrations and isotope ratios were determined by isotope dilution-multi-collector-inductively coupled plasma-mass spectrometry (ID-MC-ICP-MS), after Carius tube digestion of samples and sparging introduction of Os into the MC-ICP-MS ${ }^{43}$. PGEs in deep-sea sediments represent subequal inputs by several components, such as aeolian dust, hydrogenetic material and extraterrestrial dust, and the hydrogenetic component can be extracted from bulk samples using this method ${ }^{44}$. We also compared the $\mathrm{Re}-\mathrm{Os}$ isotope compositions obtained by inverse aqua regia and $\mathrm{CrO}_{3}-\mathrm{H}_{2} \mathrm{SO}_{4}$ digestion for the Sakahogi lower claystone samples and a Triassic chert reference material (JCh-1) issued by the Geological Survey of Japan (Supplementary Table S6). Re-Os data obtained by the two digestion methods are almost identical within analytical uncertainty. Moreover, the variation in the Os isotope records obtained by our Os analytical method for the Upper Triassic bedded cherts of the Inuyama area ${ }^{44}$ is positively correlated with marine ${ }^{87} \mathrm{Sr} /{ }^{86} \mathrm{Sr}$ and ${ }^{187} \mathrm{Os} /{ }^{188} \mathrm{Os}$ compositions ${ }^{45-47}$, indicating that Os extracted by our method from the chert samples is dominated by hydrogenous Os.

Chert and claystone samples were crushed in an agate mortar and ball mill. Chert samples of $\sim 2.5 \mathrm{~g}$ and claystone samples of $\sim 0.5$ to $\sim 2.0 \mathrm{~g}$ were dissolved and equilibrated with ${ }^{185} \mathrm{Re}$ and ${ }^{190} \mathrm{Os}$ spikes in $4 \mathrm{ml}$ of inverse aqua regia, and were heated at $220^{\circ} \mathrm{C}$ for $24 \mathrm{~h}$ in sealed Carius tubes. Re and Os concentrations and isotope ratios were determined with a Thermo Fisher Scientific Neptune MC-ICPMS. Total procedural Re and Os blanks were $7.35 \pm 0.28 \mathrm{pg}(n=6$; average \pm 1 s.d. $)$ and $0.64 \pm 0.04 \mathrm{pg}(n=9)$, respectively, with a ${ }^{187} \mathrm{Os} /{ }^{188} \mathrm{Os}$ ratio of $0.126 \pm 0.018$ $(n=9)^{43}$. Initial ${ }^{187} \mathrm{Os} /{ }^{188} \mathrm{Os}$ ratios of the chert and claystone samples were calculated using an age estimated from biostratigraphy and the astronomically tuned geomagnetic polarity time scale (215 Ma; Fig. 1$)$, and a ${ }^{187} \mathrm{Re}$ decay constant of $1.666 \times 10^{-11} \mathrm{yr}^{-1}$ (ref. 37). Full details of our sample preparation and analytical methods are described in Nozaki et al. ${ }^{43}$

Major element analysis. Major element ( $\mathrm{Si}, \mathrm{Ti}, \mathrm{Al}, \mathrm{Fe}, \mathrm{Mn}, \mathrm{Mg}, \mathrm{Ca}, \mathrm{Na}, \mathrm{K}$ and $\mathrm{P}$ ) concentrations were determined by X-ray fluorescence spectrometry (XRF). Fused glass beads for XRF analysis were made from a mixture of $\sim 0.4 \mathrm{~g}$ of powdered sample and $\sim 4 \mathrm{~g}$ of lithium tetraborate flux. All analyses were conducted with a Rigaku Simultix 12 simultaneous wavelength dispersive XRF spectrometer ${ }^{48}$. The accuracy and precision of the XRF analysis were monitored using reference materials of high-Mg basalt (SDSYB) reported by Shimoda et al. ${ }^{49}$, stream sediment (JSd-3) and chert (JCh-1) issued by the Geological Survey of Japan ${ }^{50}$.

Estimation of impactor size. The diameter of the impacting object $d$ can be calculated by the following equation, with the assumption that $0.22-1.0$ to the fraction $F$ of the impact-derived Os dissolved into seawater $6,14,34$,

$$
d=2 \times\left[\left(\frac{3 \times\left[\text { mass Os }_{\text {impactor }}(\mathrm{ng})\right] \times \frac{1}{F}}{\rho_{\text {impactor }}\left(\mathrm{g} \mathrm{cm}^{-3}\right) \times[\mathrm{Os}]_{\text {impactor }}\left(\mathrm{ng} \mathrm{g}^{-1}\right) \times 4 \pi}\right)^{1 / 3} \times 10^{-5}\right]
$$

where $\rho_{\text {impactor }}\left(\mathrm{g} \mathrm{cm}^{-3}\right)$ and $[\mathrm{Os}]_{\text {impactor }}\left(\mathrm{ng} \mathrm{g}^{-1}\right)$ denote the density and Os concentration of the impactor, respectively. The mass of Os derived from the impactor (mass $\mathrm{Os}_{\text {impactor }}(\mathrm{ng})$ ) is given by following equations ${ }^{14}$ :

$$
\begin{gathered}
{\left[\text { mass Os }_{\text {impactor }}(\mathrm{ng})\right]=\left(\frac{f}{1-f}\right) \times \text { mass } \mathrm{Os}_{\mathrm{sw}}} \\
f=\left(\frac{{ }^{187} \mathrm{Os} /{ }^{188} \mathrm{Os}_{\text {postimpact }}-{ }^{187} \mathrm{Os} /{ }^{188} \mathrm{Os}_{\text {preimpact }}}{{ }^{187} \mathrm{Os} /{ }^{188} \mathrm{Os}_{\text {impactor }}-{ }^{187} \mathrm{Os} /{ }^{188} \mathrm{Os}_{\text {preimpact }}}\right)
\end{gathered}
$$

where the seawater Os mass (mass $\mathrm{Os}_{\mathrm{sw}}$ ) is $1.4 \times 10^{19} \mathrm{ng}$ (ref. 51). ${ }^{187} \mathrm{Os}$ / ${ }^{188} \mathrm{Os}_{\text {postimpact }}$ is the ${ }^{187} \mathrm{Os} /{ }^{188} \mathrm{Os}_{i}$ ratio of the upper sublayer claystone (average ${ }^{187} \mathrm{Os} /{ }^{188} \mathrm{Os}_{i}$ ratios of four claystone samples of $\mathrm{NH} 52-\mathrm{R} 4$ to $\left.\mathrm{R} 7 ; \sim 0.222\right),{ }^{187} \mathrm{Os} /$ ${ }^{188} \mathrm{Os}_{\text {pre-impact }}$ is an average ${ }^{187} \mathrm{Os} /{ }^{188} \mathrm{Os}_{i}$ ratio of ten chert samples below claystone layer (NHR30 to NHR40; 0.582), and ${ }^{187} \mathrm{Os} /{ }^{188} \mathrm{Os}$ impactor is the ${ }^{187} \mathrm{Os} /{ }^{188} \mathrm{Os}$ ratio of the impactor.

\section{References}

1. Tanner, L. H., Lucas, S. G. \& Chapman, M. G. Assessing the record and causes of Late Triassic extinctions. Earth Sci. Rev. 65, 103-139 (2004).

2. Hallam, A. How catastrophic was the end-Triassic mass extinction? Lethaia 35, 147-157 (2002).

3. Onoue, T. et al. A deep-sea record of impact apparently unrelated to mass extinction in the Late Triassic. Proc. Natl Acad. Sci. USA 109, 19134-19139 (2012).

4. Walkden, G., Parker, J. \& Kelley, S. A late Triassic impact ejecta layer in southwestern Britain. Science 298, 2185-2188 (2002).

5. Thackrey, S. et al. The use of heavy mineral correlation for determining the source of impact ejecta: a Manicouagan distal ejecta case study. Earth Planet. Sci. Lett. 285, 163-172 (2009).

6. Alvarez, L. W., Alvarez, W., Asaro, F. \& Michel, H. V. Extraterrestrial cause of the Cretaceous-Tertiary extinction. Science 208, 1095-1108 (1980).

7. Ganapathy, R. A major meteorite impact on the earth 65 million years ago: Evidence from the Cretaceous-Tertiary boundary clay. Science 209, 921-923 (1980).

8. Peucker-Ehrenbrink, B. \& Jahn, B. Rhenium-osmium isotope systematics and platinum group element concentrations: Loess and the upper continental crust. Geochem. Geophys. Geosyst. 2, 1061 (2001).

9. Anders, E. \& Grevesse, N. Abundances of the elements: Meteoritic and solar. Geochim. Cosmochim. Acta 53, 197-214 (1989).

10. Colodner, D. C., Boyle, E. A., Edmond, J. M. \& Thomson, J. Post-depositional mobility of platinum, iridium and rhenium in marine sediments. Nature 358, 402-404 (1992).

11. Wallace, M. A., Gostin, V. A. \& Keays, R. R. Acraman impact ejecta and host shales: Evidence for low-temperature mobilization of iridium and other platinoids. Geology 18, 132-135 (1990).

12. Koeberl, C. \& Shirey, S. B. Re-Os isotope systematics as a diagnostic tool for the study of impact craters and distal ejecta. Palaeogeogr. Palaeoclimatol. Palaeoecol. 132, 25-46 (1997).

13. Luck, J. M. \& Turekian, K. K. Osmium-187/osmium-186 in manganese nodules and the Cretaceous-Tertiary boundary. Science 222, 613-615 (1983).

14. Paquay, F. S., Ravizza, G. E., Dalai, T. K. \& Peucker-Ehrenbrink, B. Determining chondritic impactor size from the marine osmium isotope record. Science 320, 214-218 (2008)

15. Peucker-Ehrenbrink, B. \& Ravizza, G. The marine osmium isotope record. Terra Nova 12, 205-219 (2000).

16. Levasseur, S., Birck, J.-L. \& Allegre, C. J. The osmium riverine flux and the oceanic mass balance of osmium. Earth Planet. Sci. Lett. 174, 7-23 (1999).

17. Ravizza, G. \& Peucker-Ehrenbrink, B. Chemostratigraphic evidence of Deccan volcanism from the marine osmium isotope record. Science 302, 1392-1395 (2003).

18. Ando, A., Kodama, K. \& Kojima, S. Low-latitude and Southern Hemisphere origin of Anisian (Triassic) bedded chert in the Inuyama area, Mino terrane, central Japan. J. Geophys. Res. 106, 1973-1986 (2001).

19. Matsuda, T. \& Isozaki, Y. Well-documented travel history of Mesozoic pelagic chert in Japan: from remote to subduction zone. Tectonics 10, 475-499 (1991).

20. Uno, K., Onoue, T., Hamada, K. \& Hamami, S. Palaeomagnetism of Middle Triassic red bedded cherts from southwest Japan: equatorial palaeolatitude of primary magnetization and widespread secondary magnetization. Geophys. J. Int. 189, 1383-1398 (2012).

21. Oda, H. \& Suzuki, H. Paleomagnetism of Triassic and Jurassic red bedded chert of the Inuyama area, central Japan. J. Geophys. Res. 105, 25743-25767 (2000).

22. Ogg, J. G. in The Geologic Time Scale 2012 (eds Gradstein, F. M., Ogg, J. G., Schmitz, M. \& Ogg, G.) 681-730 (Elsevier, 2012) 
23. Hori, R. S., Fujiki, T., Inoue, E. \& Kimura, J.-I. Platinum group element anomalies and bioevents in the Triassic-Jurassic deep-sea sediments of Panthalassa. Palaeogeogr. Palaeoclimatol. Palaeoecol. 244, 391-406 (2007).

24. Peucker-Ehrenbrink, B., Bach, W., Hart, S. R., Blusztajn, J. S. \& Abbruzzese, T. Rhenium-osmium isotope systematics and platinum group element concentrations in oceanic crust from DSDP/ODP Sites 504 and 417/418. Geochem. Geophys. Geosyst. 4, 8911 (2003).

25. Esser, B. K. \& Turekian, K. K. Accretion rate of extraterrestrial particles determined from osmium isotope systematics of Pacific Pelagic clay and manganese nodules. Geochim. Cosmochim. Acta 52, 1383-1388 (1988).

26. Ravizza, G., Sherrell, R. M., Field, M. P. \& Pickett, E. A. Geochemistry of the Margi umbers, Cyprus, and the Os isotope composition of Cretaceous seawater. Geology 27, 971-974 (1999).

27. Meisel, T., Walker, R. J. \& Morgan, J. W. The osmium isotopic composition of the Earth's primitive upper mantle. Nature 383, 517-520 (1996)

28. Robinson, N., Ravizza, G., Coccioni, R., Peucker-Ehrenbrink, B. \& Norris, R A high-resolution marine ${ }^{187} \mathrm{Os} /{ }^{188}$ Os record for the late Maastrichtian: distinguishing the chemical fingerprints of Deccan volcanism and the KP impact event. Earth Planet. Sci. Lett. 281, 159-168 (2009).

29. Meisel, T., Walker, R. J., Irving, A. J. \& Lorand, J. P. Osmium isotopic compositions of mantle xenoliths: a global perspective. Geochim. Cosmochim. Acta 65, 1311-1323 (2001).

30. Rankenburg, K., Brandon, A. D. \& Humayun, M. Osmium isotope systematics of ureilites. Geochim. Cosmochim. Acta 71, 2402-2413 (2007).

31. Rankenburg, K., Humayun, M., Brandon, A. D. \& Herrin, J. S. Highly siderophile elements in ureilites. Geochim. Cosmochim. Acta 72, 4642-4659 (2008).

32. Lodders, K. A survey of shergottite, nakhlite and chassigny meteorites wholerock compositions. Meteorit. Planet. Sci. 33, A183-A190 (1998).

33. Kitts, K. \& Lodders, K. Survey and evaluation of eucrite bulk compositions. Meteorit. Planet. Sci. 33, A197-A213 (1998).

34. Vickery, A. M. \& Melosh, H. J. Atmospheric erosion and impactor retention in large impacts, with application to mass extinctions. Geol. Soc. Am. Spec. Pap. 247, 289-300 (1990).

35. Morgan, J. W., Horan, M. F., Walker, R. J. \& Grossman, J. N. Rhenium-osmium concentration and isotope systematics in Group IIAB Iron-meteorites. Geochim. Cosmochim. Acta 59, 2331-2344 (1995).

36. Shen, J. J., Papanastassiou, D. A. \& Wasserburg, G. J. Precise Re-Os determinations and systematics of iron meteorites. Geochim. Cosmochim. Acta 60, 2887-2900 (1996).

37. Smoliar, M. I., Walker, R. J. \& Morgan, J. W. Re-Os ages of group IIA, IIIA, IVA, and IVB iron meteorites. Science 271, 1099-1102 (1996).

38. Kring, D. A. The Chicxulub impact event and its environmental consequences at the Cretaceous-Tertiary boundary. Palaeogeogr. Palaeoclimatol. Palaeoecol. 255, 4-21 (2007).

39. Schulte, P. et al. The Chicxulub asteroid impact and mass extinction at the Cretaceous-Paleogene boundary. Science 327, 1214-1218 (2010).

40. Peucker-Ehrenbrink, B. \& Ravizza, G. in The Geologic Time Scale 2012 (eds Gradstein, F. M., Ogg, J. G., Schmitz, M. \& Ogg, G.) 145-166 (Elsevier, 2012).

41. Kato, Y., Nakao, K. \& Isozaki, Y. Geochemistry of Late Permian to Early Triassic pelagic cherts from southwest Japan: implication for an oceanic redox change. Chem. Geol. 182, 15-34 (2002).

42. Retallack, G. J. et al. Search for evidence of impact at the Permian-Triassic boundary in Antarctica and Australia. Geology 26, 979-982 (1998).

43. Nozaki, T., Suzuki, K., Ravizza, G., Kimura, J.-I. \& Chang, Q. A method for rapid determination of Re and Os isotope compositions using ID-MC-ICP-MS combined with the sparging method. Geostand. Geoanal. Res. 36, 131-148 (2012).

44. Kuroda, J., Hori, R. S., Suzuki, K., Gröcke, D. R. \& Ohkouchi, N. Marine osmium isotope record across the Triassic-Jurassic boundary from a Pacific pelagic site. Geology 38, 1095-1098 (2010).

45. Korte, C., Kozur, H. W., Bruckschen, P. \& Veizer, J. Strontium isotope evolution of Late Permian and Triassic seawater. Geochim. Cosmochim. Acta 67, 47-62 (2003).

46. Cohen, A. S. \& Coe, A. L. The impact of the Central Atlantic Magmatic Province on climate and on the Sr- and Os-isotope evolution of seawater. Palaeogeogr. Palaeoclimatol. Palaeoecol. 244, 374-390 (2007).

47. Callegaro, S., Rigo, M., Chiaradia, M. \& Marzoli, A. Latest Triassic marine Sr isotopic variations, possible causes and implications. Terra Nova 24, 130-135 (2012).

48. Tani, K., Kawabata, H., Chang, Q., Sato, K. \& Tatsumi, Y. Quantitative analysis of silicate rock major and trace elements by X-ray fluorescence spectrometer: Evaluation of analytical precision and sample preparation. Front. Res. Earth Evol. 2, 1-8 (2005)

49. Shimoda, G., Tatsumi, Y., Nohda, S., Ishizaka, K. \& Jahn, B. M. Setouchi high$\mathrm{Mg}$ andesites revisited: geochemical evidence for melting of subducting sediments. Earth Planet. Sci. Lett. 160, 479-492 (1998).

50. Imai, N., Terashima, S., Itoh, S. \& Ando, A. 1996 compilation of analytical data on nine GSJ geochemical reference samples, 'Sedimentary rock series'. Geostandard Newslett. 20, 165-216 (1996).

51. Levasseur, S., Birck, J.-L. \& Allègre, C. J. Direct measurement of femtomoles of Osmium and the ${ }^{187} \mathrm{Os} /{ }^{186} \mathrm{Os}$ ratio in seawater. Science 282, 272-274 (1998).

\section{Acknowledgements}

We thank S. Kiyokawa and H. Sano of Kyushu University for insightful discussions on this research. We also thank J.-I. Kimura, Q. Chang, K. Sato, Y. Otsuki and H. Yamamoto of JAMSTEC for assistance with MC-ICP-MS and XRF analyses. We are grateful to the Japan Society for the Promotion of Science for a fellowship to H.S. This work was supported by JSPS KAKENHI Grant Numbers $24 \cdot 1374,23740378$ and 21840069 .

\section{Author contributions}

H.S. and T.O. designed this study and carried out the fieldwork and sample preparation H.S, T.N. and K.S. performed the geochemical analyses. H.S. and T.O. primarily wrote the manuscript with input from T.N. and K.S

\section{Additional information}

Supplementary Information accompanies this paper at http://www.nature.com/ naturecommunications

Competing financial interests: The authors declare no competing financial interests

Reprints and permission information is available online at http://npg.nature.com/ reprintsandpermissions/

How to cite this article: Sato, H. et al. Osmium isotope evidence for a large Late Triassic impact event. Nat. Commun. 4:2455 doi: 10.1038/ncomms3455 (2013).

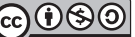

This work is licensed under a Creative Commons AttributionNonCommercial-ShareAlike 3.0 Unported License. To view a copy of this license, visit http://creativecommons.org/licenses/by-nc-sa/3.0/ 